\title{
ENANTIOSELECTIVE SYNTHESIS OF AZIRIDINES USING ASYMMETRIC TRANSFER HYDROGENATION AS A PRECURSOR FOR CHIRAL DERIVATIVES USED AS BONDING AGENT FOR ROCKET SOLID PROPELLANTS
}

\author{
Aparecida M. Kawamoto* \\ Divisão de Química, Instituto de Aeronautica e Espaço, Centro Técnico Aeroespacial, Praça Mal. Eduardo Gomes, 50, 12228-904 \\ São José dos Campos - SP, Brasil
}

Martin Wills

Department of Chemistry, University of Warwick, Coventry, CV4 7AL, UK

Recebido em 27/7/01; aceito em 13/3/02

\begin{abstract}
A rapid, expedient and enantioselective method for the synthesis of $\beta$-hydroxy amines and monosubstituted aziridines in up to 99\% e.e., via asymmetric transfer hydrogenation of a-amino ketones and cyclisation through treatment with tosyl chloride and base, is described. $(1 R, 2 R)-\mathrm{N}$-(para-toluenesulfonyl)-1,2-ethylenediamine with formic acid has been utilised as a ligand for the Ruthenium (II) catalysed enantioselective transfer hydrogenation of the ketones.The chiral 2-methyl aziridine, which is a potentially more efficient bonding agent for Rocket Solid Propellant has been successfully achieved.
\end{abstract}

Keywords: aziridines; transfer hydrogenation; bonding agent.

\section{INTRODUCTION}

The synthesis of chiral compounds in optically pure form represents a major challenge for the organic chemist. The development of novel methods of synthesizing optically pure aziridines and their derivatives is an area of growing importance. Chiral aziridines are known to be useful electrophilic synthetic intermediates for asymmetric synthesis because of their high reactivity and ability to function as carbon electrophiles. They have shown biological properties and are pivotal targets for the synthesis of chiral functionalized compounds. They are a rich source of important pharmaceuticals and adrenoceptor blocking agents ${ }^{1}$. Their derivatives have been studied as possible agents for the treatment of certain types of cancer. Among the agents of interest of cancer chemotherapy are the phosphorus aziridines derivatives such as compounds (1), $(\mathbf{2})^{2}$, (3) and (4) ${ }^{3}$.

Phosphoaziridines (3) and (4) have been shown in experimental and clinical studies to be potent antitumor agents as well as radiation sensitizers ${ }^{4}$.

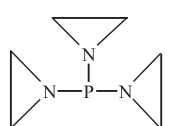

(1)

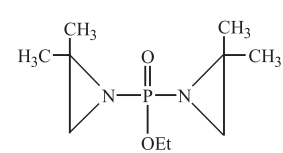

(3)

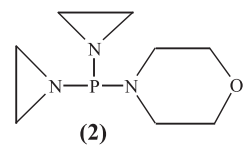

(2)

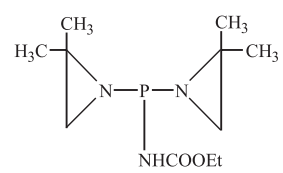

(4) *e-mail: amkawamoto@hotmail.com
Some aziridine derivatives are also known as bonding agents for solid propellants which have a high potential to improve the mechanical properties of the propellant grains composed of the fuelbinder, hydroxyl terminated polybutadiene (HTPB) and the solid fillers, ammonium perchlorate (AP) and aluminium powder 5 .

$\mathrm{Nema}^{6}$ described the main function of the bonding agent as the enhancement of the adhesive force due to either the primary chemical tie of the functional groups to AP or the secondary polar attraction.

Up to the present, many aziridine derivatives have been tested and two of them, (5) and (6), have been used very successfully. ${ }^{7}$ Compound (5) is a phosphorus aziridine tris[1-(2-methyl)aziridinyl]phosphine oxide (MAPO) and (6) is an aromatic aziridine isophthalic 2-methyl aziridine (HX-752).

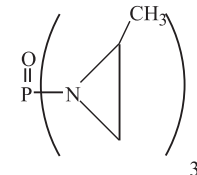

(5) MAPO

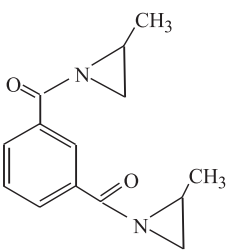

(6) HX-752
These bonding agents have been prepared in racemic form by reacting methyl aziridine with phosphorus oxychloride and Isophthaloyl dichloride respectively (Scheme 1).

In the diagram below are illustrated the hypothetical interaction between $\mathrm{AP}$ and the bonding agents $(\mathbf{5})$ and $(\mathbf{6})^{5,5 \mathrm{~b}}$.

While racemic aziridines and their derivatives are readly available, procedures for their synthesis in enantiomerically pure form are limited. The synthesis of enantiomerically pure aziridines is a desirable objective since the physiological properties of both the aziridines themselves and the products formed from them are likely to be dependent on the absolute configuration. ${ }^{8}$ Ring closure of $\beta$ amino alcohols, derived from amino acids, is one frequently used 


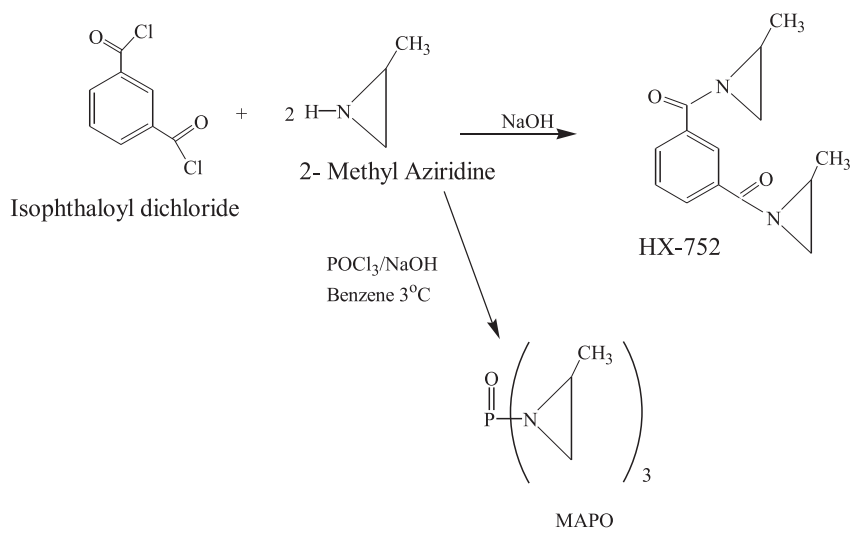

Scheme 1.

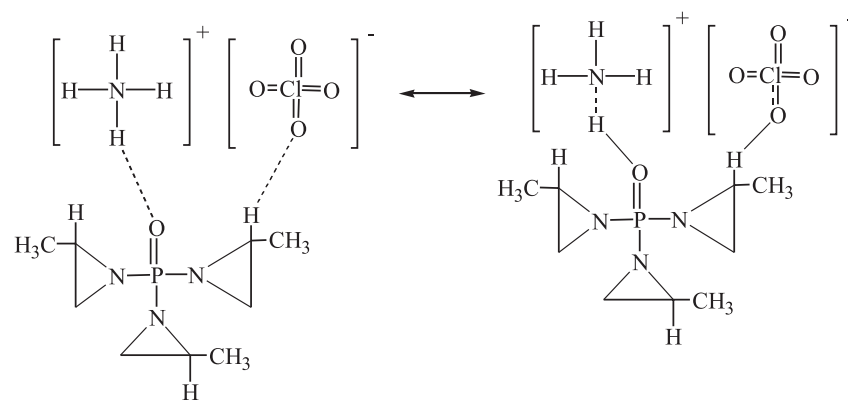

Figure 1. Hypothetical intermolecular interaction between AP and bonding agent MAPO

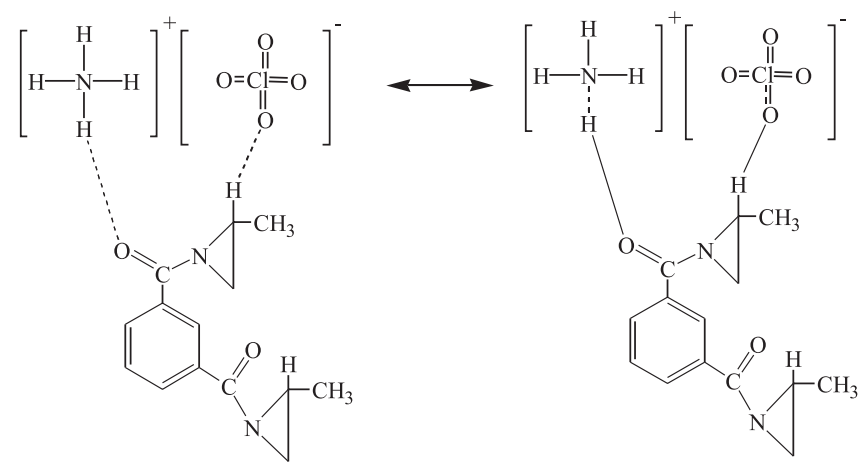

Figure 2. Hypothetical intermolecular interaction between AP and bonding agent $H X-752$

method for the synthesis, but it is limited by the availability of the starting material. ${ }^{9}$ In this paper we describe a simple and expedient route for the enantioselective synthesis of aziridines via $\alpha$-amido ketone reduction followed by cyclisation.

Also described is a future approach for the synthesis of the bonding agent derivatives MAPO and HX-752 and some chiral analogues of them.

\section{RESULTS AND DISCUSSION}

The reduction of ketones using enantioselective transfer hydrogenation has already been described ${ }^{10-12}$ (Scheme 2). A combination of $(1 S, 2 R)$-cis-aminoindanol 7 with $\left[\mathrm{Ru}(\text { cymene }) \mathrm{Cl}_{2}\right]_{2}$ and isopropanol/KOH as the hydrogen source ${ }^{12 a}$, gave a product of $79 \%$ e.e. It was later found that the combination of $(R, R)$-TsDPEN 8 with the same ruthenium complex, a system first reported by Noyori ${ }^{10}$, gave superior results (Scheme 2) when used with the formic acid/ triethylamine hydrogen source ${ }^{12 b}$.

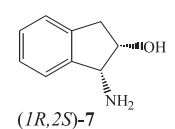

$(1 R, 2 S)-7$

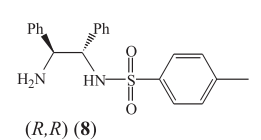

$(R, R)(8)$

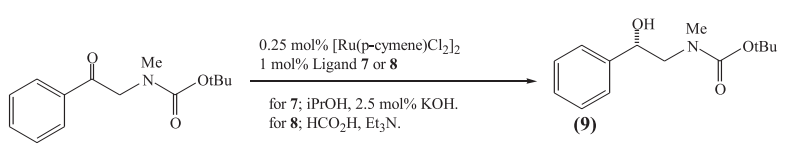

Using $(1 R, 2 S)-1 ; 86 \%$ yield, $79 \%$ e.e Using $(R, R)-2 ; 82 \%$ yield, $99 \%$ e.e.

Scheme 2.

Since the enantioselectivies of the reduction were high, we used this method for the synthesis of aziridines, and as for the racemic reduction, it was carried out using sodium borohydride. Aziridines were prepared by one pot cyclization with tosyl chloride and $\mathrm{KOH}$ of chiral N-protected $\beta$-aminoalcohols.

Scheme 3 outlines the synthetic route used to obtain $N-t$ Boc-2methyl aziridine and the further reactions to be followed for their derivatives.

$N$-tBoc protection of the amino alcohol 10 gave $( \pm) t$ Boc-1-aminopropan-2-ol 11 in $99 \%$ yield. Following a sequence of reactions to the aziridines, compound $\mathbf{1 1}$ was then cyclised to the $N$ - $t$ Boc aziridine (racemic) 15 through treatment with tosyl chloride and base (57\% yield), and also oxidised with pyridium dichromate to give ( \pm )-1$t$ Boc amino propan-2-one $\mathbf{1 2}$ in $88 \%$ yield. Asymmetric reduction of 12 using the ruthenium based catalyst, TsDPEN and formic acid gave the corresponding chiral alcohol $\mathbf{1 3}$ in $87 \%$ yield and $[\alpha]_{\mathrm{d}}{ }^{20}$ $+27.5\left(\mathrm{c}=1 \mathrm{CH}_{2} \mathrm{Cl}_{2}\right)$, which was cyclised to $N$ - $t$ Boc-2-methyl aziridine $R-(-)-14$ in $56 \%$ yield and $[\alpha]_{\mathrm{d}}^{20}-42.2\left(\mathrm{c}=1 \mathrm{CH}_{2} \mathrm{Cl}_{2}\right)$, through treatment with tosyl chloride and base. The $R$ configuration was expected since the cyclisation process normally occurs with an inversion of configuration. Since the alcohol and the aziridine are not UV active, the exact enantiomeric excess of the pure compound could not be measured by chiral HPLC, however since both have high $[\alpha]_{\mathrm{d}}^{20}$ value we can then conclude that it is of high e.e.

A further reaction of the aziridines (14) and (15), after the $t$-Boc deprotection with TFA/DCM, with phosphorus oxychloride and isophthaloyl dichloride should give the bonding agents MAPO and HX-752 in the racemic forms already synthesized previously and also in their chiral form for the first time.

Seeking other aziridines that would lead to analogues of the bonding agents (5) and (6), the synthesis of $N$ - $t$ Boc-1-phenyl aziridine was also an objective of our study.

The total synthesis was achieved in several steps (Scheme 4), starting with $t$ Boc-protection of the $\mathrm{NH}$ group of $( \pm)$-2-amino-1phenylethanol (16) affording ( \pm )-phenyl-(2-tert-butoxy carbonyl amino)ethanol (17) in $95 \%$ yield, which was then oxidised with pyridinium dichromate, to give the corresponding ( \pm ) 2-N-tertbutoxycarbonyl amino acetophenone (18) in $88 \%$ yield. Enantioselective reduction of ketone (18) using (1S,2R)-cis-amino indanol/Ru(II)/isopropanol system gave the corresponding alcohol S-(+) (19) in $86 \%$ yield and $99 \%$ ee as measured by chiral HPLC. The configuration of $S-(+)-\mathbf{1 9}$ was determined by deprotection of 

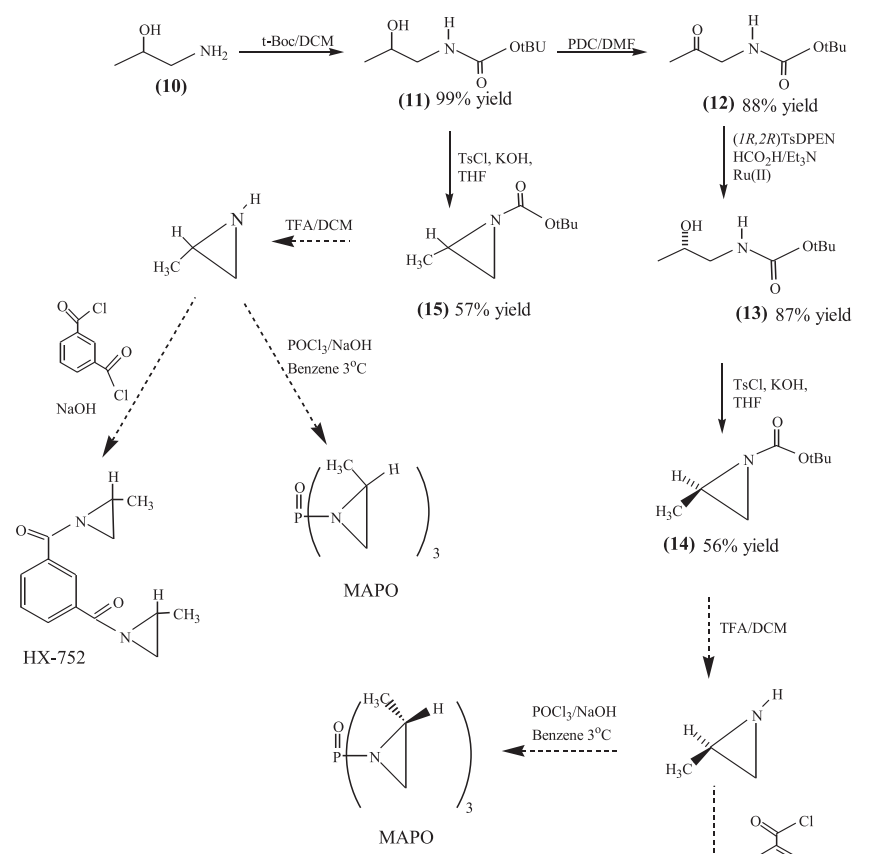

(14) $56 \%$ yield

HX-752

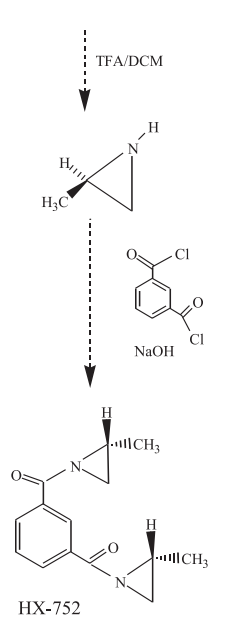

Scheme 3.

the nitrogen atom with TFA to give the known aminoalcohol $S$-(+)22 in $27 \%$ yield.

Alcohol $S$-(+)-19 was cyclised to the $N$ - $t$ Boc-aziridine $R-(-)-20$ in $83 \%$ yield through treatment with tosyl chloride and base ${ }^{13}$. Cyclisation of racemic ( \pm )-1-phenyl-(2-tert-butoxy carbonyl amino) ethanol (19) to the $( \pm) N$ - $(t$ Boc $)-1$-pheny aziridine (21) was achieved in $92 \%$ yield through treatment with tosyl chloride and base (in order to obtain a racemic standard). Further deprotection of the $t$-Boc group with TFA/DCM and reaction with phosphorus oxychloride and isophthaloyl dichloride might provide some other analogues of the bonding agents (5) and (6) in both racemic and chiral form.

\section{CONCLUSION}

Considering the importance of the bonding agents in the formulation of the solid propellants regarding mechanical and ballistic properties, there is a constant search for analogues or novel compounds which might improve these properties. Moroever there is a need for compounds that might be used in small quantity, therefore reducing the final cost of the propellant.

Another purpose of this study was the synthesis of aziridine derivatives which would be tested as potential bonding agents for rocket solid propellants and to make a comparative study with the bonding agents in current use. This work is ongoing.

In conclusion, we have demonstrated that the use of a monotosylated diamine/formic acid/triethylamine and cis-1-amino2-indanol/isopropanol systems are highly effective for the enantioselective reduction of $t$ Boc-protected a-aminoketones and this

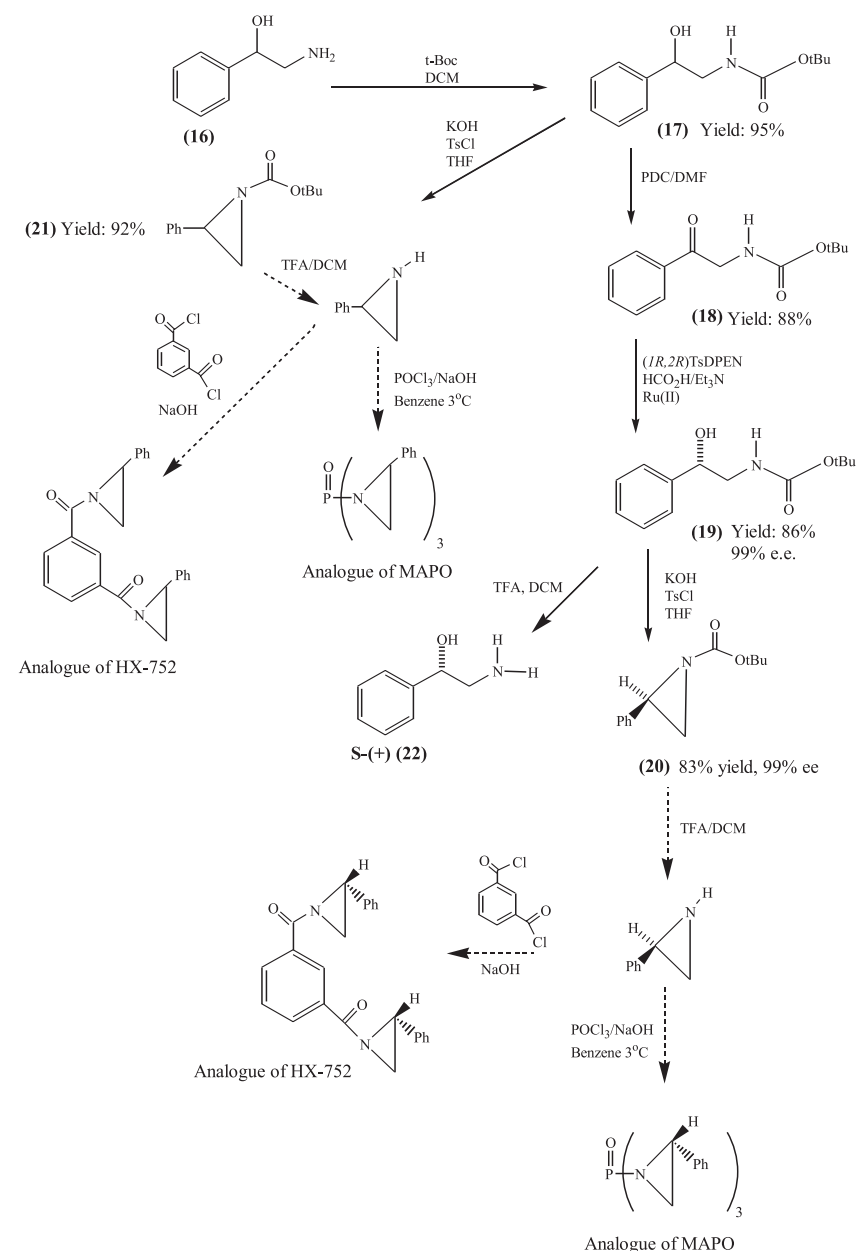

Scheme 4.

process provides an efficient method for the enantioselective syntheses of enantiomerically enriched b-amino alcohol and aziridines.

\section{EXPERIMENTAL}

All reactions, unless otherwise stated, were run under an atmosphere of nitrogen. Room temperature refers to ambient temperature $\left(20-22{ }^{\circ} \mathrm{C}\right), 0{ }^{\circ} \mathrm{C}$ refers to an ice slush bath and $-78^{\circ} \mathrm{C}$ refers to a dry ice-acetone bath. Heated experiments were conducted using thermostatically controlled oil baths.

Reactions were monitored by TLC using aluminium backed silica gel 60 (F254) plates, visualised using UV 254nm and PMA, nihydrin or potassium permanganate dips as appropriate. Flash column chromatography was carried out routinely using $60 \AA$ Silica gel (Merck).

Reagents were used as received from commercial sources unless otherwise stated. Acetophenone were purified by short path distillation before use. Formic acid:triethylamine $(5: 2)$ is a commercially available azeotrope (Fluka).

NMR spectra were recorded on a Bruker DPX (300 MHz) spectrometer. The spectra solutions in deutered chloroform $\left(\mathrm{CDCl}_{3}\right)$ unless otherwise stated. Chemical shifts are reported in $\delta$ units, parts per million downfield from TMS. Coupling constants $(J)$ are measured in hertz. IR spectra were recorded on a Perkin Elmer 1310 FTIR instrument using sodium chloride plates. Mass spectra were recorded on a 7070E VG mass spectrometer. Melting point were recorded on a Stuart Scientific SMP 1 instrument and are uncorrected. Optical rotations were mesured with a AA-1000 polarimeter. 
(士) N-(tBoc)-1-aminopropan-2-ol (11)

To a solution of ( \pm )-1-aminopropan-2-ol (10) $(2.0 \mathrm{~g}, 26.62 \mathrm{mmol})$ in dichloromethane $(50 \mathrm{~mL})$, triethylamine $(3.95 \mathrm{~g}, 15.0 \mathrm{mmol})$ followed by di-tert-butyldicarbonate $(2.18 \mathrm{~g}, 39.0 \mathrm{mmol})$ were added. The reaction mixture was stirred overnight, then saturated ammonium chloride solution $(30 \mathrm{~mL})$ was added. The phases were separated and the aqueous layer extracted with dichloromethane $(2 \times 30 \mathrm{~mL})$. The combined organic layers were dried over magnesium sulphate, filtered, and the solvent removed in vacuo. Purification by flash chromatography on silica with ethyl acetate-petroleum ether 40:60, gave the compound as colourless liquid of high viscosity $(4.44 \mathrm{~g}, 95.3 \%) ; \mathrm{v}_{\max }\left(\right.$ neat $\left./ \mathrm{cm}^{-1}\right)$ : 2977, 1685, 1517, 1363, 1276, 1159, 1108, 976, 750; $\delta_{\mathrm{H}}(300 \mathrm{MHz}$, $\left.\mathrm{CDCl}_{3}\right) 1.17\left(3 \mathrm{H}, \mathrm{d}, \mathrm{J} 6.41, \mathrm{CH}_{3}\right), 1.45\left(9 \mathrm{H}, \mathrm{s}, \mathrm{C}\left(\mathrm{CH}_{3}\right)\right), 2.95-3.04(2$ $\mathrm{H}, \mathrm{m}, \mathrm{CH}, \mathrm{OH}), 3.23-3.29(1 \mathrm{H}, \mathrm{m}, \mathrm{CH}), 3.88-3.90(1 \mathrm{H}, \mathrm{m}, \mathrm{CH})$, $5.12(1 \mathrm{H}$, brs, $\mathrm{NH}) ; \delta_{c}\left(75.5 \mathrm{MHz}, \mathrm{CDCl}_{3}\right) 20.32\left(\mathrm{CH}_{3}\right), 28.47$ $\left(\left(\mathrm{CH}_{3}\right)_{3} \mathrm{C}\right), 47.91\left(\mathrm{CH}_{2}\right), 67.06(\mathrm{CH}), 79.83\left(\left(\mathrm{CH}_{3}\right)_{3} \mathrm{C}\right), 164.25(\mathrm{C}=\mathrm{O})$; $\mathrm{m} / \mathrm{z}$ (FAB) $176\left([\mathrm{M}+\mathrm{H}]^{+}\right.$74\%), 154(6), 137(9), 120(100), 103(13); (Found: $[\mathrm{M}+\mathrm{H}]^{+}, 176.1286 . \mathrm{C}_{8} \mathrm{H}_{17} \mathrm{NO}_{3}$ requires $\mathrm{m} / z, 176.1287$ ).

\section{( \pm ) N-(tBoc)-1-aminopropan-2-one (12)}

(士)-1-Aminopropan-2-ol (11) (1.0 g, $5.71 \mathrm{mmol})$ was added to an ice cold solution of pyridinium dichromate $(6.44 \mathrm{~g}, 17.13 \mathrm{mmol})$ in anhydrous $N, N$-dimethylformamide $(20 \mathrm{~mL})$. The reaction mixture was stirred overnight, then worked up with brine $(30 \mathrm{~mL})$. The compound was extracted with diethyl ether $(3 \times 30 \mathrm{~mL})$. The combined organic layers were dried over anhydrous magnesium sulphate, filtered and concentrated under reduced pressure to give the crude compound which was purified by flash chromatography eluting with ethyl acetatepetroleum ether 40:60 to give $( \pm) N$ - $(t$ Boc $)-1$-aminopropan-2-one as a colourless liquid $(0.88 \mathrm{~g}, 88.0 \%) ; v_{\max }\left(\right.$ neat $\left./ \mathrm{cm}^{-1}\right) 3357,2977,2926$, $1699,1510,1356,1283,1247,1159,1071,955,882,779 ; \delta_{\mathrm{H}}(300$ $\left.\mathrm{MHz}, \mathrm{CDCl}_{3}\right) 1.45\left(9 \mathrm{H}, \mathrm{s}, \mathrm{C}\left(\mathrm{CH}_{3}\right)_{3}\right), 2.18\left(3 \mathrm{H}, \mathrm{s}, \mathrm{CH}_{3}\right), 4.03(2 \mathrm{H}, \mathrm{d}$, $J$ 4.71, $\left.\mathrm{CH}_{2}\right), 5.24(1 \mathrm{H}$, brs, $\mathrm{NH}) ; \delta_{\mathrm{c}}\left(75.5 \mathrm{MHz}, \mathrm{CDCl}_{3}\right) 27.49\left(\mathrm{CH}_{3}\right)$, $28.69\left(\left(\mathrm{CH}_{3}\right)_{3} \mathrm{C}\right), 51.31\left(\mathrm{CH}_{2}\right), 80.23\left(\left(\mathrm{CH}_{3}\right)_{3} \mathrm{C}\right), 164.05(\mathrm{C}=\mathrm{O}) ; \mathrm{m} / \mathrm{z}$ (CI) $174\left([\mathrm{M}+\mathrm{H}]^{+} 100 \%\right), 163(12), 147(25)$; (Found: $[\mathrm{M}+\mathrm{H}]^{+}$, 174.1127. $\mathrm{C}_{8} \mathrm{H}_{15} \mathrm{NO}_{3}$ requires $m / z$ 174.1130).

\section{(+) N-(tBoc)-1-aminopropan-2-ol (13)}

A mixture of ( $p$-cymene) ruthenium (II) chloride dimer (0.62 mg, $0.010 \mathrm{mmol})$ and $(1 R, 2 R)$-TsDPEN $(0.74 \mathrm{mg}, 0.02 \mathrm{mmol})$ in a $5: 2$ formic acid/triethylamine mixture $(3.0 \mathrm{~mL})$ was stirred at 28 ${ }^{\circ} \mathrm{C}$ for $15 \mathrm{~min} .( \pm) N$ - $(t$ Boc $)-1$-aminopropan-2-one $(\mathbf{1 2})(0.70 \mathrm{~g}, 4.04$ $\mathrm{mmol}$ ) was added and the solution was stirred at $28^{\circ} \mathrm{C}$ for $\quad 24$ $\mathrm{h}$. Then the mixture was filtered through silica and washed with ethyl acetate $(60 \mathrm{ml})$. The solvent was evaporated under reduced pressure to give the crude compound, which was purified by flash chromatography (ethyl acetate/petroleum ether 40:60) to give the compound as a colourless liquid $(0.62 \mathrm{~g}, 87.3 \%)$. $[\alpha]^{20}{ }_{\mathrm{D}}+27.5$ (c=2 dichloromethane); $v_{\max }\left(\right.$ neat $\left./ \mathrm{cm}^{-1}\right) 3355,2974,2934,1691,1528,1458,1393,1368,1276$, $1252,1173,1039,991,942,901,865,838 ; \delta_{\mathrm{H}}\left(300 \mathrm{MHz}, \mathrm{CDCl}_{3}\right)$ $1.18\left(3 \mathrm{H}, \mathrm{d}, J 6.41, \mathrm{CH}_{3}\right), 1.45\left(9 \mathrm{H}, \mathrm{s}, \mathrm{C}\left(\mathrm{CH}_{3}\right)\right), 2.96-3.05(2 \mathrm{H}, \mathrm{m}$, $\mathrm{CH}, \mathrm{OH}), 3.23-3.30(1 \mathrm{H}, \mathrm{m}, \mathrm{CHH}), 3.85-3.95(1 \mathrm{H}, \mathrm{m}, \mathrm{CHH}), 5.01$ ( $1 \mathrm{H}$, brs, $\mathrm{NH}) ; \delta_{\mathrm{c}}\left(75.5 \mathrm{MHz}, \mathrm{CDCl}_{3}\right) 21.03\left(\mathrm{CH}_{3}\right), 28.75\left(\left(\mathrm{CH}_{3}\right)_{3} \mathrm{C}\right)$, $48.35\left(\mathrm{CH}_{2}\right), 68.09(\mathrm{CH}), 80.07\left(\left(\mathrm{CH}_{3}\right)_{3} \mathrm{C}\right), 155.60(\mathrm{C}=\mathrm{O}) ; \mathrm{m} / \mathrm{z}(\mathrm{FAB})$ $176\left([\mathrm{M}+\mathrm{H}]^{+} 27 \%\right), 155(100), 154(100), 136(80), 120(50), 107(31)$; (Found: $[\mathrm{M}+\mathrm{H}]^{+}, 176.1279 . \mathrm{C}_{8} \mathrm{H}_{17} \mathrm{NO}_{3}$ requires $\mathrm{m} / z, 176.1287$ ).

\section{(-) N-(tBoc)-1-methyl aziridine (14)}

To a solution of (+) $N$-( $t$ Boc)-1-aminopropan-2-ol (13) (1.0 g, 5.71 mmol) and tosyl choride $(1.63 \mathrm{~g}, 8.56 \mathrm{mmol})$ in dry THF $(20 \mathrm{~mL})$ was added $\mathrm{KOH}(1.60 \mathrm{~g}, 28.55 \mathrm{mmol}$ ) freshly powered (with the help of a ball mill) at room temperature. The reaction mixture was left stirring overnight. Then it was dissolved in diethyl ether $(40 \mathrm{~mL})$ and filtered. The solvent was removed under reduced pressure and the crude compound was purified using flash chromatography eluting with ethyl acetate-petroleum ether 40:60 to give the aziridine as a colourless liquid $(0.50 \mathrm{~g}, 55.7 \%) .[\alpha]^{20}{ }_{\mathrm{D}}-42.2\left(\mathrm{c}=1\right.$ dichloromethane); $v_{\max }\left(\right.$ neat $\left./ \mathrm{cm}^{-1}\right)$ 3064, 2977, 2932, 1718, 1600, 1475, 1458, 1407, 1393, 1368, 1310, $1257,1224,1154,1088,1063,1028,940,908,867,831,769 ; \delta_{\mathrm{H}}(300$ $\left.\mathrm{MHz}, \mathrm{CDCl}_{3}\right) 1.27\left(3 \mathrm{H}, \mathrm{d}, \mathrm{J} 5.5, \mathrm{CH}_{3}\right), 1.46\left(9 \mathrm{H}, \mathrm{s},\left(\mathrm{CH}_{3}\right)_{3} \mathrm{C}\right), 1.89(1$ $\left.\mathrm{H}, \mathrm{d}, J 3.8, \mathrm{CH} H_{\mathrm{az}}\right), 2.24\left(1 \mathrm{H}, \mathrm{d}, J 5.8, \mathrm{CH} \mathrm{H}_{\mathrm{az}}\right), 2.24-2.49(1 \mathrm{H}, \mathrm{m}$, $\left.\mathrm{CH}_{\mathrm{az}}\right) ; \delta_{\mathrm{c}}\left(75.5 \mathrm{MHz}, \mathrm{CDCl}_{3}\right) 17.77\left(\mathrm{CH}_{3}\right), 28.31\left(\left(\mathrm{CH}_{3}\right)_{3} \mathrm{C}\right), 32.86$ $\left(\mathrm{CH}_{2}\right), 33.95(\mathrm{CH}), 81.29\left(\left(\mathrm{CH}_{3}\right)_{3} \mathrm{C}\right), 162.58(\mathrm{C}=\mathrm{O}) ; \mathrm{m} / \mathrm{z}(\mathrm{FAB}) 158$ $\left([\mathrm{M}+\mathrm{H}]^{+} 16 \%\right), 156(10), 128(6), 119(15), 108(37), 58(100)$; (Found: $[\mathrm{M}+\mathrm{H}]^{+}, 158.1181 . \mathrm{C}_{8} \mathrm{H}_{15} \mathrm{NO}_{2}$ requires $\left.m / z, 158.1181\right)$.

\section{(士) N-(tBoc) -1-methyl aziridine (15)}

To a solution of ( \pm ) $N$ - $(t$ Boc)-1-aminopropan-2-ol (11) (2.0 g, 11.41 mmol) and tosyl choride ( $3.05 \mathrm{~g}, 15.98 \mathrm{mmol})$ in dry THF $(40 \mathrm{~mL})$ was added $\mathrm{KOH}$ (3.10 g, $56.11 \mathrm{mmol}$ ) freshly powered (with the help of a ball mill) at room temperature. The reaction mixture was left stirring overnight. Then it was dissolved in diethyl ether $(50 \mathrm{~mL})$ and filtered. The solvent was removed under reduced pressure and the crude compound was purified using flash chromatography eluting with ethyl acetate-petroleum ether 40:60 to give the aziridine as a colourless liquid $(1.27 \mathrm{~g}, 56.7 \%) \cdot v_{\max }\left(\right.$ neat $\left./ \mathrm{cm}^{-1}\right) 3006,2989,1714,1451,1275,1260$, 1159,$749 ; \delta_{\mathrm{H}}\left(300 \mathrm{MHz}, \mathrm{CDCl}_{3}\right) 1.22\left(3 \mathrm{H}, \mathrm{d}, J 5.6, \mathrm{CH}_{3}\right), 1.41(9 \mathrm{H}, \mathrm{s}$, $\left.\left(\mathrm{CH}_{3}\right)_{3} \mathrm{C}\right), 1.82\left(1 \mathrm{H}, \mathrm{d}, J 3.8, \mathrm{CH}_{\mathrm{az}}\right), 2.19\left(1 \mathrm{H}, \mathrm{d}, J 5.8 \mathrm{CHH}_{\mathrm{az}}\right), 2.14-$ $2.43\left(1 \mathrm{H}, \mathrm{m}, \mathrm{CH}_{\mathrm{az}}\right) ; \delta_{\mathrm{c}}\left(75.5 \mathrm{MHz}, \mathrm{CDCl}_{3}\right) 17.28\left(\mathrm{CH}_{3}\right), 28.12\left(\left(\mathrm{CH}_{3}\right)_{3} \mathrm{C}\right)$, $32.41\left(\mathrm{CH}_{2}\right), 33.69(\mathrm{CH}), 80.92\left(\left(\mathrm{CH}_{3}\right)_{3} \mathrm{C}\right), 162.58(\mathrm{C}=\mathrm{O}) ; \mathrm{m} / \mathrm{z}(\mathrm{FAB})$ $158\left([\mathrm{M}+\mathrm{H}]^{+} 16 \%\right), 156(10), 128(6), 119(15), 108(37), 58(100)$; (Found: $[\mathrm{M}+\mathrm{H}]^{+}, 158.1181 . \mathrm{C}_{8} \mathrm{H}_{15} \mathrm{NO}_{2}$ requires $\left.m / z, 158.1181\right)$.

\section{(土)N-(tBoc)-2-amino-1-phenylethanol (17)}

To a solution of $( \pm$ )-2-amino-1-phenylethanol (16) (1.37 g, 10.0 $\mathrm{mmol})$ in dichloromethane $(30 \mathrm{~mL})$, triethylamine $(1.52 \mathrm{~g}, 15.0$ $\mathrm{mmol})$ followed by di-tert-butyldicarbonate $(2.18 \mathrm{~g}, 10.0 \mathrm{mmol})$ were added. The reaction mixture was stirred overnight then saturated ammonium chloride solution $(30 \mathrm{~mL})$ added. The phases were separated and the aqueous layer extracted with dichloromethane $(2 \mathrm{x}$ $30 \mathrm{~mL}$ ). The combined organic layers were dried over magnesium sulphate, filtered, and the solvent removed in vacuo to give the compound as a white solid $(2.25 \mathrm{~g}, 95 \%)$, m.p. $120-121^{\circ} \mathrm{C} ; v_{\max }$ (Nujol/ $\left.\mathrm{cm}^{-1}\right) 3362,1675,1531,1276,1166,1957,962,903,750 ; \delta_{\mathrm{H}}(300$ $\left.\mathrm{MHz}, \mathrm{CDCl}_{3}\right) 1.44\left(9 \mathrm{H}, \mathrm{s}, \mathrm{CH}_{3}\right), 3.18-3.27(1 \mathrm{H}, \mathrm{m}, \mathrm{CH} H), 3.39$ (1 $\mathrm{H}$, brs, $\mathrm{OH}), 3.42-3.49(1 \mathrm{H}, \mathrm{m}, \mathrm{CHH}), 4.78-4.81(1 \mathrm{H}, \mathrm{m}, \mathrm{CH}), 5.03$ ( $1 \mathrm{H}$, brs, $\mathrm{NH}), 7.26-7.35\left(5 \mathrm{H}, \mathrm{m}\right.$, Aryl H); $\delta_{\mathrm{c}}\left(75.5 \mathrm{MHz}, \mathrm{CDCl}_{3}\right)$ $28.75\left(\left(\mathrm{CH}_{3}\right)_{3} \mathrm{C}\right), 48.73\left(\mathrm{CH}_{2}\right), 74.3(\mathrm{CH}), 80.23\left(\left(\mathrm{CH}_{3}\right)_{3} \mathrm{C}\right), 126.28$, 128.16, 128.87, 142.22 (Ar-ipso), $157.36(\mathrm{C}=\mathrm{O}) ; \mathrm{m} / \mathrm{z}$ (FAB) 238 $\left([\mathrm{M}+\mathrm{H}]^{+} 40 \%\right), 182(63), 164(100), 154(29), 137(26), 120(29)$; (Found: $[\mathrm{M}+\mathrm{H}]^{+}, 238.1449 . \mathrm{C}_{13} \mathrm{H}_{19} \mathrm{NO}_{3}$ requires $m / z, 238.1443$ ).

\section{2-N-(tert-Butoxycarbonyl)aminoacetophenone (18)}

( \pm ) $N$ - $(t$ Boc)-2-amino-1-phenylethanol (17) $(2.55 \mathrm{~g}, 10.75$ mmol) was added to an ice cold solution of pyridinium dichromate (15.0 g, $39.83 \mathrm{mmol})$ in anhydrous N,N-dimethylformamide $(50 \mathrm{~mL})$. The reaction mixture was stirred overnight, then worked up with brine $(60 \mathrm{~mL})$. The compound was extracted with diethyl ether $(3 \mathrm{x}$ $60 \mathrm{~mL}$ ). The combined organic layers were dried over anhydrous 
magnesium sulphate, filtered and concentrated under reduced pressure to give the crude compound which was purified by flash chromatography eluting with 10\% ethyl acetate-petroleum ether 40:60 to give 2- $N$-(tert-butoxycarbonyl) aminoacetophenone as a white solid (2.23 g, 88.1\%), m.p. $55-58{ }^{\circ} \mathrm{C} ; v_{\max }\left(\mathrm{CDCl}_{3} / \mathrm{cm}^{-1}\right) 3425,2970,1685$, $1582,1488,1444,1363,1217,1159,1049,984,903,867 ; \delta_{\mathrm{H}}(300$ $\mathrm{MHz}_{\mathrm{CDCl}}$ ) 1.48 (9 H, s, $\left.\mathrm{CH}_{3}\right), 4.66\left(2 \mathrm{H}, \mathrm{d}, \mathrm{J} 4.52, \mathrm{CH}_{2}\right), 5.60$ (1 $\mathrm{H}$, brs, $\mathrm{NH}), 746-7.97(5 \mathrm{H}, \mathrm{m}$, Aryl $\mathrm{H}) ; \delta_{\mathrm{c}}\left(75.5 \mathrm{MHz}, \mathrm{CDCl}_{3}\right)$ $28.74\left(\left(\mathrm{CH}_{3}\right)_{3} \mathrm{C}\right), 47.89\left(\mathrm{CH}_{2}\right), 80.19\left(\left(\mathrm{CH}_{3}\right)_{3} \mathrm{C}\right), 128.20,129.24$, 134.30, 134.92 (Ar-ipso), $156.15(\mathrm{C}=\mathrm{O}), 193.5(\mathrm{C}=\mathrm{O}) ; \mathrm{m} / z(\mathrm{FAB})$ $236\left([\mathrm{M}+\mathrm{H}]^{+}\right.$23\%), $180(87), 154(27), 136(100), 105(30), 97(47)$; (Found: $[\mathrm{M}+\mathrm{H}]^{+}, 236.1284 . \mathrm{C}_{13} \mathrm{H}_{17} \mathrm{NO}_{3}$ requires $\mathrm{m} / z$ 236.1287).

\section{(S) N-(tBoc)-2-amino-1-phenyl ethanol (19)}

A mixture of ( $p$-cymene) ruthenium (II) chloride dimer $(0.34 \mathrm{mg}$, $0.006 \mathrm{mmol})$ and $(1 R, 2 R)$-TsDPEN $(0.40 \mathrm{mg}, 0.011 \mathrm{mmol})$ in a $5: 2$ formic acid/triethylamine mixture $(3.0 \mathrm{~mL})$ was stirred at $28{ }^{\circ} \mathrm{C}$ for 15 min. 2- $N$-(tert-Butoxycarbonyl) aminoacetophenone (19) (0.50 g, 2.13 mmol) was added and the solution was stirred at $28{ }^{\circ} \mathrm{C}$ for 24 hours. Then the mixture was filtered through silica and washed with ethyl acetate $(60 \mathrm{ml})$. The solvent was evaporated under reduced pressure to give the crude compound, which was purified by flash chromatography (ethyl acetate/petroleum ether 40:60) to give the compound as a white solid $(0.44 \mathrm{~g}, 83.6 \%)$. The product was determined to be of $99 \%$ e.e. by HPLC analysis (Chiral OD, hexane:ethanol:diethylamine $=$ 95:5:0.1 (0.5 mL/ $\mathrm{min}), S$ isomer $17.86 \mathrm{~min}, R$ isomer $19.49 \mathrm{~min}$, m.p.

$66-$ $68{ }^{\circ} \mathrm{C} ;[\alpha]^{20}{ }_{\mathrm{D}}+3.5(\mathrm{c}=1$ ethanol $) ; v_{\max }\left(\mathrm{CDCl}_{3} / \mathrm{cm}^{-1}\right) 3423,2978,2931$, 1693, 1514, 1454, 1392, 1367, 1251, 1170, 1094, 1065, 910, 733, 700; $\delta_{\mathrm{H}}\left(300 \mathrm{MHz}, \mathrm{CDCl}_{3}\right) 1.43\left(9 \mathrm{H}, \mathrm{s}, \mathrm{CH}_{3}\right), 3.16-3.25(1 \mathrm{H}, \mathrm{m}, \mathrm{CH} H)$, 3.41-3.47 (1 H, m, CHH), $3.56(1 \mathrm{H}$, brs, $\mathrm{OH}), 4.76-4.79(1 \mathrm{H}, \mathrm{m}$, $\mathrm{CH}(\mathrm{OH})), 5.08$ ( $1 \mathrm{H}$, brs, $\mathrm{NH}), 7.24-7.34(5 \mathrm{H}, \mathrm{m}$, Aryl $\mathrm{H}) ; \delta_{\mathrm{c}}(75.5$ $\left.\mathrm{MHz}, \mathrm{CDCl}_{3}\right) 28.75\left(\left(\mathrm{CH}_{3}\right)_{3} \mathrm{C}\right), 48.70\left(\mathrm{CH}_{2}\right), 74.19(\mathrm{CH}), 80.19$ $\left(\left(\mathrm{CH}_{3}\right)_{3} \mathrm{C}\right), 126.29,128.14,128.85,142.24$ (Ar-ipso), $157.34(\mathrm{C}=\mathrm{O})$; $\mathrm{m} / \mathrm{z}$ (FAB) $238\left([\mathrm{M}+\mathrm{H}]^{+}\right.$52\%), 182(72), 164(100), 154(40), 137(35), 120(30); (Found: $[\mathrm{M}+\mathrm{H}]^{+}, 238.1448 . \mathrm{C}_{13} \mathrm{H}_{19} \mathrm{NO}_{3}$ requires $m / z, 238.1443$ ).

\section{(R) N -(tBoc)-1-phenylaziridine (20)}

To a solution of (S) $N$-( $t$ Boc)-2-amino-1-phenyl ethanol (19) $(0.3 \mathrm{~g}, 1.10 \mathrm{mmol})$ and tosyl choride $(0.23 \mathrm{~g}, 1.20 \mathrm{mmol})$ in dry THF $(20 \mathrm{~mL})$ was added $\mathrm{KOH}(0.30 \mathrm{~g}, 5.40 \mathrm{mmol})$ freshly powered (with the help of a ball mill) at room temperature. The reaction mixture was left stirring overnight. Then it was dissolved in diethyl ether $(30 \mathrm{~mL})$ and filtered. The solvent was removed under reduced pressure to give a pale oil as a pure aziridine $(0.22 \mathrm{~g}, 92.0 \%)$. The product was determined to be $99 \%$ e.e. by chiral shift reagent ([Eu(hf) $\left.\left.{ }_{3}\right], 6 \mathrm{~mol} \%\right),[\alpha]^{20}{ }_{\mathrm{D}}-137$ (c=2 ethanol); $v_{\max }\left(\right.$ neat $\left./ \mathrm{cm}^{-1}\right) 3408$, 3058, 2977, 2933, 1719, 1663, 1597, 1473, 1318, 1155, 1020, 962, 852,$765 ; \delta_{\mathrm{H}}\left(300 \mathrm{MHz}, \mathrm{CDCl}_{3}\right) 1.44\left(9 \mathrm{H}, \mathrm{s},\left(\mathrm{CH}_{3}\right)_{3} \mathrm{C}\right), 2.26(1 \mathrm{H}, \mathrm{d}$, $\left.J 3.5, \mathrm{CH} H_{\mathrm{az}}\right), 2.62\left(1 \mathrm{H}, \mathrm{d}, J 6.2, \mathrm{CH}_{\mathrm{az}}\right), 3.42(1 \mathrm{H}, \mathrm{dd}, J 3.5,6.2$, $\left.\mathrm{CH}_{\mathrm{az}}\right), 7.24-7.33\left(5 \mathrm{H}, \mathrm{m}\right.$, Aryl H); $\delta_{\mathrm{c}}\left(75.5 \mathrm{MHz}, \mathrm{CDCl}_{3}\right) 28.29$ $\left(\left(\mathrm{CH}_{3}\right)_{3} \mathrm{C}\right), \quad 35.24\left(\mathrm{CH}_{2}\right), 39.70(\mathrm{CH}), 81.82\left(\left(\mathrm{CH}_{3}\right)_{3} \mathrm{C}\right), 126.73$, $128.15,128.84,137.66$ (Ar-ipso), $162.54(\mathrm{C}=\mathrm{O}) ; \mathrm{m} / \mathrm{z}$ (CI) 220 $\left([\mathrm{M}+\mathrm{H}]^{+}\right.$97\%), 181(77), 164(100), 146(10), 120(18); (Found: $[\mathrm{M}+\mathrm{H}]^{+}, 220.1332 . \mathrm{C}_{13} \mathrm{H}_{17} \mathrm{NO}_{2}$ requires $\mathrm{m} / \mathrm{z}, 220.1338$ ).

\section{( \pm ) N-(tBoc)-2-phenylaziridine (21)}

To a solution of $( \pm) N$-( $t$ Boc $)-2$-amino-1-phenyl ethanol (17) $(0.3 \mathrm{~g}, 1.10 \mathrm{mmol})$ and Tosyl choride $(0.23 \mathrm{~g}, 1.20 \mathrm{mmol})$ in dry THF $(20 \mathrm{~mL})$ was added $\mathrm{KOH}(0.30 \mathrm{~g}, 5.40 \mathrm{mmol})$ freshly powered (with the help of a ball mill) at room temperature. The reaction mixture was left stirring overnight. It was then dissolved in diethyl ether $(30 \mathrm{~mL})$ and filtered. The solvent was removed under reduced pressure to give a pale oil as a pure aziridine $(0.22 \mathrm{~g}, 92.0 \%) . v_{\max }$ (neat/ $\left.\mathrm{cm}^{-1}\right) 1717,1655,1469,1391,1317,1303,1280,1253,1229,1153$, 852, 794; $\delta_{\mathrm{H}}\left(300 \mathrm{MHz}, \mathrm{CDCl}_{3}\right) 1.50\left(9 \mathrm{H}, \mathrm{s},\left(\mathrm{CH}_{3}\right)_{3} \mathrm{C}\right), 2.31(1 \mathrm{H}, \mathrm{d}$, $\left.J 3.58, \mathrm{CH} H_{\mathrm{az}}\right), 2.67\left(1 \mathrm{H}, \mathrm{d}, J 6.40, \mathrm{CHH}_{\mathrm{az}}\right), 3.48(1 \mathrm{H}, \mathrm{dd}, J 3.58$, 6.41, $\left.\mathrm{CH}_{\mathrm{az}}\right), 7.31-7.40(5 \mathrm{H}, \mathrm{m}, \operatorname{Aryl~H}) ; \delta_{\mathrm{c}}\left(75.5 \mathrm{MHz}, \mathrm{CDCl}_{3}\right) 28.29$ $\left(\left(\mathrm{CH}_{3}\right)_{3} \mathrm{C}\right), 35.24\left(\mathrm{CH}_{2}\right), 39.70(\mathrm{CH}), 81.76\left(\left(\mathrm{CH}_{3}\right)_{3} \mathrm{C}\right), 126.74$, $128.15,128.84,137.67(\mathrm{Ar}), 162.52(\mathrm{C}=\mathrm{O}) ; \mathrm{m} / z(\mathrm{CI}) 220\left([\mathrm{M}+\mathrm{H}]^{+}\right.$ 47\%), 181(100), 164(90), 146(10), 120(70); (Found: $[\mathrm{M}+\mathrm{H}]^{+}$, 220.1334. $\mathrm{C}_{13} \mathrm{H}_{17} \mathrm{NO}_{2}$ requires $\left.m / z, 220.1338\right)$.

\section{ACKNOWLEDGMENTS}

We thank CNPq for a Scholarship to A.K. and Professor D. Games and Dr B. Stein of the EPSRC National Mass Spectroscopic service (Swansea) for HRMS analysis of some compounds. We wish to acknowledge the use of the EPSRC's Chemical Database Service at Daresbury ${ }^{14}$.

\section{REFERENCES}

1. Rauf, A.; Ahmad, M. S.; Ahmad, F.; Osman, S. M.; J. Am. Oil Chem. Soc. 1984, 61, 959

2. King, R. B.; von Stetten, O.; Inorg. Chem. 1974, 13, 2449.

3. Perlman, M. E.; Bardos, T. J.; J. Org. Chem. 1988, 53, 1761.

4. Bardos, T. J.; Ambrus, J. L.; Ambrus, C. M.; J. Surg. Oncol. 1971, 3, 431; Wampler, G. L.; Kuperminc, M.; Regelson, W.; Cancer Chemother. Pharmacol. 1980, 4, 49; Belgrad, R.; Wampler, G. L.; Int. J. Radiat. Oncol. Biol. Phys. 1982, 8, 1219.

5. Kori, K.; Iwama, A.; Propellants, Explos., Pyrotech. 1985, 10, 176; Hori, K.; Iwama, A.; Propellants, Explos., Pyrotech. 1990, 15, 99.

6. Hasegawa, K.; Takizuka, M.; Fukuda, T.; AIAA Papers 1983, 83, 1199.

7. Allen, H. C.; US pat. 3,745,074, 1973.

8. For a comprehensive survey of methods of aziridine synthesis from double bonds, including a discussion of cyclisations of b-amino alcohols see; Kemp J. E. G. In Comprehensive Organic Synthesis, Academic Press, 1991, vol. 7, ch. 3.5, pp 470-483; Atkinson, R. S.; Kelly, B. J.; J. Chem. Soc, Chem. Commun. 1987, 1362.

9. Evans, D. A.; Faul, M. M.; Bilodeau, M. T.; J. Org. Chem. 1991, 113, 726; Li, Z.; Conser, K. R.; Jacobsen, E. N.; J. Am. Chem. Soc. 1993, 115, 5326; Evans, D. A.; Faul, M. M.; Bilodeau, M. T.; Anderson, B. A.; Barnes, D.; J. Am. Chem. Soc. 1993, 115, 5328; Haddadin, M. J.; Freeman, J. P.; Small Ring Heterocycles; Hassner, NY, A. ed.; 1985, part 3, p. 283; Paredes, R.; Bastosm, H.; Montoya, R.; Charez, A. L.; Dolbier, W. R. Jr.; Burkholder, C. R.; Tetrahedron 1988, 44, 6821; Azman, A.; Kroller, J.; Plesnicar, B.; J. Am. Chem. Soc. 1970, 101, 1107.

10. Monotosylated diamines with $\mathrm{Ru}(\mathrm{II})$ in $\mathrm{iPrOH}$ or $\mathrm{HCO}_{2} \mathrm{H} / \mathrm{TEA}$ : Hashiguchi, S.; Fujii, A.; Takehara, J.; Ikariya, T.; Noyori, R.; J. Am. Chem. Soc. 1995, 117, 7562; Fujii, A.; Hashiguchi, S.; Uematsu, N.; Ikariya, T.; Noyori, R.; J. Am. Chem. Soc. 1996, 118, 2521; Püntener, K.; Schwink, L.; Knochel, P.; Tetrahedron Lett. 1996, 37, 8165. Monotosylated diamines with Rh(III) in iPrOH: Mashima, K.; Abe, T.; Tani, K.; Chem. Lett. 1998, 1199; Mashima, K.; Abe, T; Tani, K.; Chem. Lett. 1998, 1201; Murata, K.; Ikariya, T.; Noyori, R.; J. Org. Chem. 1999, 64, 2186.

11. Palmer, M., J.; Wills, M.; Tetrahedron: Asymmetry 1999, 10, 2045; Palmer, M.; Walsgrove, T.; Wills, M.; J. Org. Chem. 1997, 62, 5226; Wills, M.; Gamble, M.; Palmer, M.; Smith, A. R. C.; Studley, J. R.; Kenny, J. A.; J. Mol. Catal. A 1999, 146, 139; Smith, A. R. C.; Kenny, J. A.; Heck, A. J. R.; Kettenes-van der Bosch, J. J.; Wills, M.; Tetrahedron: Asymmetry 1999, 10, 3267; Wills, M.; Palmer, M., J.;. Smith, A. R. C; Kenny, J. A.; Walsgrove, T.; Molecules 2000, 5, 1; Kenny, J. A.; Versluis, K.; Heck, A. J. R.; Walsgrove, T.; Wills, M.; Chem. Commun 2000, 99.

12. Kenny, J. A.; Palmer, M. J.; Smith, A. R. C.; Walsgrove, T.; Wills, M.; Synlett. 1999, 1615; Kawamoto, A.; Wills, M.; Tetrahedron Asymmetry 2000, 11, 3257.

13. Wessig, P.; Schwarz, J.; Synlett 1997, 893.

14. Fletcher, D. A.; McMeeking, R. F.; Parkin, D.; J. Chem. Inf. Comput. Sci. 1996, 36, 746 . 